\title{
Sedimentation pathways in the Indian sector of the Southern Ocean during a production regime dominated by regeneration
}

\author{
Caroline Cailliau' ${ }^{1}$, Sauveur Belviso ${ }^{2, *}$, Madeleine Goutx ${ }^{3}$, Alain Bedo ${ }^{4}$, \\ Young Park ${ }^{5}$, Edwige Charriaud ${ }^{5,+}$
}

\author{
${ }^{1}$ LPCM, UPMC-CNRS-INSU, BP 08, 06230 Villefranche-sur-Mer, France \\ ${ }^{2}$ LSCE, UMR CEA-CNRS, av. de la Terrasse, 91198 Gif-sur-Yvette, France \\ ${ }^{3}$ LMM, CNRS-EP 2032, Campus de Luminy, Case 907, 13288 Marseille Cédex 9, France \\ ${ }^{4}$ LOBE, Station Zoologique, La Darse, 06230 Villefranche-sur-Mer, France \\ ${ }^{5}$ LOP, 43 rue Cuvier, 75005 Paris, France
}

\begin{abstract}
During summer 1994, the production regime at 2 sites located in the Indian sector of the Southern Ocean, one in the Permanent Open Ocean Zone (POOZ) at $52^{\circ} \mathrm{S}$, and a second in the Seasonal Ice Zone (SIZ) at $63^{\circ} \mathrm{S}$, was dominated by regeneration $(0.3<f$-ratio $<0.4)$. Two time series, each of about $4 \mathrm{~d}$, were performed over pre-determined time intervals of $4 \mathrm{~h}$ using a free-floating sediment trap set at $200 \mathrm{~m}$ at the 2 sites. Hourly variations of C, N, chlorophyll a (chl a) and its degradation products, taxon-specific pigments, lipid classes and dimethylsulfoniopropionate (DMSP) were measured simultaneously. Measurements in the water column were done during the sediment trap drifting. Fucoxanthin, a typical diatom pigment, was the major accessory pigment found in the trap material at the 2 stations, whereas, in the water column, the phytoplankton was dominated by flagellates in the POOZ and diatoms in the SIZ. This suggests selective grazing of diatoms by zooplankton and/or mass sinking of diatoms, at least in the POOZ. However, since the set of compounds exhibited strong diel cycles in the POOZ, the export flux appears to mainly result from the zooplankton. The results are ambiguous as to whether the intensified sedimentation at night resulted from vertical migration of euphausiids, since copepods crossing the pycnocline were rare, and/or the nocturnal increast of feeding activity of copepods and microzooplankton. At the SIZ, diatoms dominated in the mixed ldyer and at the deep phytoplankton maximum (DPM) located at the depth of the temperature minimum (50 to $100 \mathrm{~m}$ ). However, pigment signature in the trap material suggested the selective sedimentation of nanoflagellates (essentially pelagophytes). Correspondingly, there was high proportions of sterols up to $40 \%$ in the trap material. The diel variations somewhat resembling POOZs, the low chl a-to-phaeopigments ratio and the presence of phaeopigments in their most degraded forms were strong indications of the key role played by zooplankton in the export fluxes in the SIZ. Hence, the selective feeding of phytoplanktor by zooplankton strongly influenced the sedimentation pathways in the Indian Sector of the Southern Ocean. Additionally, DMSP, which is produced by phytoplankton in superficial waters, is shown to be as labile as chl a when processed by grazers.
\end{abstract}

KEY WORDS: Antarctic Austral Ocean Sediment traps - Diel cycles - Phytoplankton - Pigments Lipids DMSP DNIS

\section{INTRODUCTION}

Investigating the way in which open-ocean material flux is transported to depth is of crucial importance for a better understanding of the role of oceans in the atmospheric budget of carbon dioxide and of the func-

-E-mail: belviso@psce.saclay.cea.fr

†Deceased 22 June 1999 tioning of the 'biological pump'. The knowledge of the phytoplankton community structure is of great interest since it most likely influences sedimentation and carbon flux (von Bodungen et al. 1986, 1988, Cullen 1991, Jacques \& Panouse 1991, Boyd \& Newton 1999). The 'regenerated' system, also called the 'microbial loop' system (Jacques 1989, Lancelot et al. 1989) and generally characterized by nanoflagellates, is assumed to be a weak exporter of organic matter to the deep layers 
(Bak et al. 1992), while a large fraction of organic matter produced in the 'new' production system, generally characterized by diatoms (Jacques 1991, Claustre 1994), is exported into deep water and sediments through the rapid sinking of large diatoms, fecal pellets and marine snow (Jacques 1991, Scharek et al. 1994). In the Southern Ocean, however, a shift from 'new' to 'regenerated' production can proceed with or without a shift in phytoplankton community structure, and dominance of diatoms in a system where regenerated production was predominant has been observed (L. Goeyens pers. comm.). Our paper investigates the late austral summer 1994 sedimentation pathways in the Indian sector of the Southern Ocean associated with a regenerated production regime and a phytoplanktonic composition described by Cailliau et al. (1997) and Fiala et al. (1998).

Although the theoretical and experimental studies carried out so far have shown the potential importance of considering short-term variations when studying the dynamics and the export flux of particulate matter from the mixed layer (Welschmeyer et al. 1984 , Lampitt et al. 1993, Corn et al. 1994, Ruiz 1997), we are not aware of any observations of particle fluxes with high temporal resolution (hours) in high-nutrient-lowchlorophyll waters of the Southern Ocean. By measuring simultaneously in the sediment trap and water column samples $C, N$, chlorophyll a $(\mathrm{chl}$ a) and its phaeopigments, taxonomic pigments, lipid classes and the total pool of dimethylsulfoniopropionate (DMSP) + DMS (DMS $(\mathrm{P}))$, we investigated the dynamics of the export flux and the sedimentation pathways of the phytoplanktonic material during short-term drifter experiments performed at 2 sites in the Indian sector of the Southern Ocean.

Table 1. Data sets from sediment trap and bottle samplings. POOZ: Permanent Open Ocean Zone; SIZ: Seasonal Ice Zone

\begin{tabular}{|c|c|c|c|c|c|c|c|c|}
\hline Site & Area $^{a}$ & Station & $\begin{array}{c}\text { Date } \\
\text { (Feb 94) }\end{array}$ & $\begin{array}{l}\text { Time } \\
\text { (local) }\end{array}$ & $\begin{array}{l}\text { TPC, } \\
\text { PON }\end{array}$ & $\begin{array}{l}\text { Pig- } \\
\text { ments }\end{array}$ & DMSP & Lipids \\
\hline \multicolumn{9}{|l|}{ Bottles } \\
\hline \multirow[t]{2}{*}{ POOZ } & 2 & 3 & 10 & $21: 30$ & + & + & + & + \\
\hline & 3 & 13 & 13 & $09: 15$ & + & + & + & - \\
\hline \multirow[t]{4}{*}{ SIZ } & 1 & N19 & 19 & $12: 00$ & + & + & - & - \\
\hline & 1 & $\mathrm{~N} 20$ & 20 & $13: 00$ & + & + & + & - \\
\hline & 1 & N21 & 21 & 11:00 & + & - & - & + \\
\hline & 2 & 23 & 21 & $23: 30$ & + & - & - & + \\
\hline \multicolumn{9}{|l|}{ Traps } \\
\hline \multirow[t]{2}{*}{ POOZ } & 2 & Start & 10 & $20: 00$ & & & & \\
\hline & 3 & End & 14 & $20: 00$ & + & + & + & $\pm^{b}$ \\
\hline \multirow[t]{2}{*}{ SIZ } & 1 & Start & 19 & 00:00 & & & & \\
\hline & 1 & End & 22 & $16: 00$ & + & + & + & $\pm^{\mathrm{b}}$ \\
\hline \multicolumn{9}{|c|}{${ }^{\mathrm{a}}$ As shown in Fig. 2} \\
\hline
\end{tabular}

\section{MATERIALS AND METHODS}

We carried out 2 experiments at sea over periods of $4 \mathrm{~d}$ as part of the JGOFS-France ANTARES project during February and March 1994 on RV 'Marion Dufresne' (ANTARES II cruise). Site A01 was located at $52^{\circ} \mathrm{S}, 62^{\circ} \mathrm{E}$, in the Permanent Open Ocean Zone (POOZ) south of the Polar Front Zone (PFZ). Site A04 was located at $63^{\circ} \mathrm{S}, 70^{\circ} \mathrm{E}$ in the Seasonal Ice Zone (SIZ). Our strategy to investigate the export flux sedimentation pathways was to compare the water column and the sediment trap materials. The spatio-temporal resolutions of the parameters investigated were whenever possible the same (Table 1). Lipids which have higher time and financial costs show lower spatio-temporal resolution than total particulate carbon (TPC), particulate organic nitrogen (PON), pigments and DMSP.

Bottle samplings. Water column samples were taken during the sediment trap drifting either by a CTD rosette sampler, equipped with 121 Niskin bottles, or by hydrocasts during the temporary failure of the CTD rosette sampler in the SIZ.

Sediment trap samplings. Sedimenting particle samples were collected using a free-drifting sediment trap (Technicap, PPS5/2) which had a $1 \mathrm{~m}^{2}$ mouth area and was able to sample sequentially up to 24 samples each of $250 \mathrm{ml}$. Sequential flux samples were collected over $4 \mathrm{~h}$ sampling periods. In the POOZ, the drifting sediment trap was deployed at position $D$ and recovered at position R (Fig. 1a). The hydrological measurements were not systematically carried out along the mean drifter trajectory shown in Fig. 1a by a dashed line. From the 20 CTD profiles it was possible to identify 3 areas with distinct hydrological characteristics. Area 1 was out of the drifting domain so only Areas 2 and 3 are investigated in detail. In the SIZ, due to the CTD failure, hydrological measurements were scarce. Nevertheless, 2 areas were identified (Fig. 1b). The traps were located just below the photic zone $(200 \mathrm{~m})$, so that decomposition of particulate matter during its vertical descent was minimized, and thus vertical fluxes of organic particulate matter represent export production. No fixative solution was added because of the short duration of deployments at sea and the low temperature of polar waters. Salinity of water in the sample bottles was raised to $40 \%$ to prevent losses by diffusion. After trap recovery, living or dead mesozooplankton trapped inside the sampling cups were systematically removed so that only detrital particles and organisms $<1 \mathrm{~mm}$ 


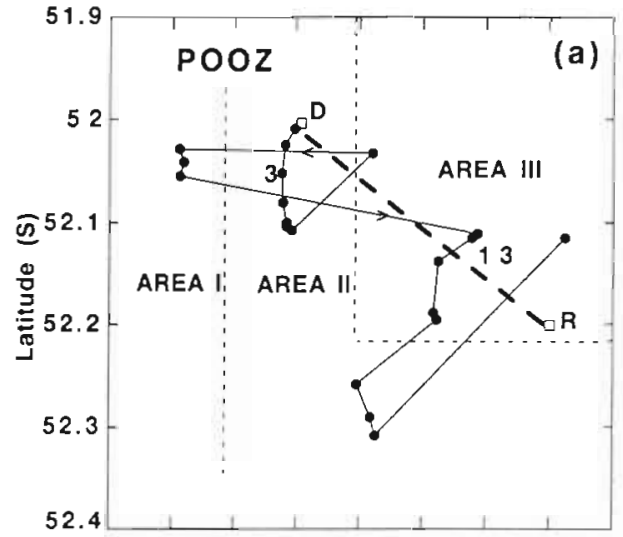

61.761 .861 .96262 .162 .262 .362 .462 .5

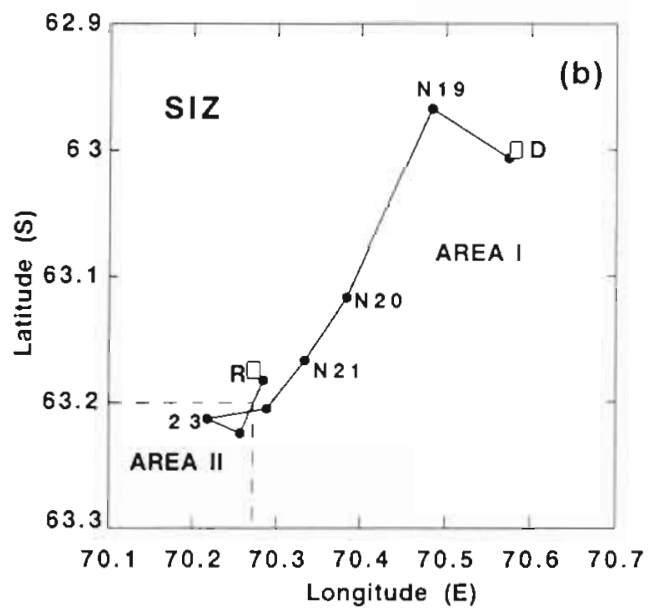

Fig. 1. Cruise track and positions of CTDs and hydrocasts (•) during the sediment trap deployments in (a) the Permanent Open Ocean Zone (POOZ) and (b) the Seasonal Ice Zone (SIZ). Drifting trap was deployed at position $D$ and recovered at position $\mathrm{R}$. Areas were delimited from the analysis of the hydrological records (see Fig. 3)

were analysed. After resuspension, we used volumetric splitting to produce aliquots for the subsequent analyses

Pigment analysis. Water samples (2 l) and sediment trap samples (30 to $50 \mathrm{ml}$ ) were filtered through $25 \mathrm{~mm}$ GF/F Whatman filters, at a vacuum differential inferior to $20 \mathrm{~cm} \mathrm{Hg}$. Filters were stored in liquid nitrogen before laboratory analysis using HPLC (high performance liquid chromatography). Methods are described in Cailliau et al. (1997).

The chemotaxonomic significance of pigments recorded in this study is as follows. Chl a is the marker of total autotrophic biomass. The sum of $19^{\prime}$-hexanoyloxyfucoxanthin (HEX) and 19'-butanoyloxyfucoxanthin (BUT) concentrations characterizes the abundance of nanoflagellates (prymnesiophytes and pelagophytes respectively), while fucoxanthin (FUCO) is most likely a diatom marker (Wright \& Jeffrey 1987, Wright et al.
1991). Although some species of the prymnesiophyte Phaeocystis may contain significant amounts of FUCO (Buma et al. 1991), there is evidence that this contribution remains low for Antarctic strains (Wright \& Jeffrey 1987, Vaulot et al. 1994, Bidigare et al. 1996). The possible contribution of Phaeocystis to the FUCO signal is here assumed to be negligible.

The chl a degradation products of grazing and senescence are, descending to the most degraded form, phaeophytin $a$, phaeophorbide $a$ and pyrophaeophorbide $a$. These are all detected by HPLC. The identification of the different phaeopigments was realized by comparing retention time and visible absorption spectra with those of standards provided by D.J. Repeta (Department of Chemistry, Woods Hole Oceanographic Institution). Since grazing provides also colorless products, not detected by HPLC, the phaeopigments were used here as qualitative and not quantitative indices of zooplankton grazing.

The $F_{\mathrm{p}}$-ratio (dimensionless, $0<F_{\mathrm{p}}<1$ ), defined as the sum of FUCO and peridinin concentrations divided by the sum of concentrations of all accessory pigments, characterizes the proportion of microphytoplankton within the phytoplankton community in the water column (Claustre 1994, Cailliau et al. 1997). The $T_{\mathrm{p}}$-ratio (dimensionless, $0<T_{\mathrm{p}}<1$ ), here defined as the sum of FUCO and peridinin fluxes ( $\left.\mu \mathrm{g} \mathrm{m}^{-2} 4 \mathrm{~h}^{-1}\right)$ at $200 \mathrm{~m}$. divided by the sum of fluxes of all accessory pigments, characterizes the proportion of microphytoplankton within the whole phytoplankton community that is exported downwards

Lipid classes. Water column samples were filtrated and stored in the same conditions as pigments. Aliquots of 30 to $50 \mathrm{ml}$ of the sediment trap cups were lyophilized and extracted according to the Bligh \& Dyer (1959) procedure. Lipid classes were separated on chromarods SIII and analysed on a Iatroscan TH 10 apparatus model MK-IV (hydrogen flow, $160 \mathrm{ml} \mathrm{min}^{-1}$; air flow, $2000 \mathrm{ml} \mathrm{min}^{-1}$ ) coupled to a compatible PC-AT equipped with a Boreal integration system (Flotec company, Paris). The separation scheme involved 4 elution steps in solvent systems of increasing polarity. Two successive solvent systems followed by partial scannings, hexane (100\%) (15 min) and hexane + diethylether + formic acid $(85+10+0.1)(40 \mathrm{~min})$, mobilized the neutral lipid classes: hydrocarbons $(\mathrm{HC})$ in the first system followed by wax esters (WE) co-eluting with sterol esters (SE) generally in little amount in natural particulate material, ketone (KET) as internal standard, triglycerides (TG), free fatty acids (FFA), alcohols (ALC), diglycerides (DG) and ST (ST). A third solvent system (15 min in $100 \%$ acetone) mobilized the chloroplast lipids (AMPL), which included pigments and glycolipids in addition to monoglycerides. A last elution system (40 min in chloroform + methanol $+28 \%$ 
ammonium hydroxide, $50+50+5$ ) separated successively non-nitrogen-containing phospholipids (diphosphatidylglycerides co-eluting with phosphatidylglycerides, PG) from nitrogen-containing phospholipids (phosphatidylethanolamine [PE], and phosphatidylcholine [PC]). Each analysis was run in duplicate (several samples were run in triplicate to control the SD). Total lipids (TL) are the sum of the different classes. The relative standard deviation of replicate samples $(\mathrm{n}=3$ ) for Iatroscan TLC-FID analyses was 3 to $11 \%$. Lipid concentrations given in the text are the average of 2 to 3 analyses. Only half of the total number of flux samples was analysed for lipid classes. The equivalent carbon of $1 \mu \mathrm{g}$ TL $(0.72 \mu \mathrm{g} C)$ - noted TL(C) - was calculated assuming an average standard lipid class composition comparable to the composition of sediment trap lipid extracts.

The quality and quantity of lipids in suspended particles $(<200 \mu \mathrm{m})$ are an indicator of the presence of microplanktonic organisms, cell physiology and of the degradation status of organic matter (see Parrish 1988 for a review). In the present work, WE were used as an indicator of zooplankton sources (Sargent 1978, Wakeham 1982, Cavaletto et al. 1989, Kattner 1989). The AMPL were related to the presence of phytoplankton cells (Parrish \& Wangersky 1987, Volkman \& Hallegraeff 1988, Volkman et al. 1989, Goutx et al. 1990). ST, although detected in numerous species of copepods (Ohman 1988), are widely distributed among marine microalgae (Volkman 1986, Volkman et al. 1989), in prymnesiophyceae in particular (Volkman et al. 1990, 1993). The degradation status of organic matter can be estimated from the presence of acyl-lipid breakdown products (FFA and ALC) liberated in the medium through the activity of esterase enzymes (Weeks et al. 1993, Parrish et al. 1995, Volkman et al. 1989). Weeks et al. (1993) found a significant relationship between the increase of the FFA + ALC to TG + WE + FFA + ALC ratio and increasing rates of mesozooplankton grazing in the North Atlantic. In the present study, we used the lipolysis index (LI), that is the ratio of these labile metabolites to the entire acyl-lipids (ALC + FFA to WE $+\mathrm{TG}+\mathrm{AMPL}+\mathrm{PG}+\mathrm{PE}+\mathrm{PI}+\mathrm{PC}$ ), as an indicator of the early stage of organic matter biodegradation.

Carbon and nitrogen measurements. Replicate particulate carbon and nitrogen analyses were carried out on 5 to $40 \mathrm{ml}$ subsamples of trap material filtered onto pre-ashed glass fiber filters (Whatman GF/F) and stored at $-20^{\circ} \mathrm{C}$. Samples from the water column were treated in the same ways. The filters were then dried at $60^{\circ} \mathrm{C}$ and TPC and PON determined using a Perkin Elmer 2400 elemental analyser.

DMSP measurements. Eukaryotic marine phytoplankton appears to be the principal source of DMSP (Keller et al. 1989, Corn et al. 1996). Concentrations of particulate DMSP (DMSPp) in seawater and DMS $(P)$ downward fluxes were measured on board following the procedures of Belviso et al. (1993) and Corn et al (1994), respectively. DMS(P) in the traps is assumed to be transported vertically in the form of DMSPp but can undergo transformation within the sampling jars to form dissolved DMSP (DMSPd) and DMS. Resuspension provided efficient mixing of all physical and chemical forms and analysis of the whole aliquot prevented losses and underestimations of DMS(P) fluxes

\section{RESULTS}

\section{Hydrology and meteorology}

The time series in the POOZ started at 20:00 h llocal time) on February 10 and ended at 20:00 h on February 14 (Fig. 2a). During this period, the meteorological conditions changed markedly from windy to stormy weather with the passage of a low pressure system (995 mbar, Fig. 2a) centred on February 12 in the morning with wind speeds in the range 15 to $21 \mathrm{~m} \mathrm{~s}^{-1}$. Mean vertical profiles of potential temperature, salinity and excess potential density are shown in Fig. 3. Waters in the upper $160 \mathrm{~m}$ in Area 3 were about half a degree warmer, slightly less salty and consequently lighter than in Area 2. The mixed layer depth at Area 2 was about $80 \mathrm{~m}$ while Area 3 showed very slight thermal stratification between 30 and $80 \mathrm{~m}$ depth. From the dates of the CTD profiles it is possible to estimate the transition from Area 2 to Area 3 before February 11 at 16:00 h (local time), that is within a day after the start of the sediment trap time series. Thus the trap most probably crossed a front during its deployment.

The time series at the SIZ started at 00:00 h (local time) on February 19, and ended at 16:00 h on February 22 (Fig. 2b). During this period, a low pressure system was established and clear diel variations in wind speed were observed with values in a low range (1 to $3 \mathrm{~m} \mathrm{~s} \mathrm{~s}^{-1}$ ) during the day and increasing markedly during the night up to $12 \mathrm{~m} \mathrm{~s}^{-1}$ (Fig. 2b). The mean physical features of the SIZ are given in Fig. 3. Area 2 had a shallower mixed layer, cooler subsurface waters at the depth of the temperature minimum and a deeper thermocline than Area 1.

\section{Vertical distribution of carbon and related com- pounds in the 0 to $200 \mathrm{~m}$ water column}

POOZ

Since TPC, pigments and DMSP were measured in the POOZ at Stns 3 and 13 (Table 1), it was possible to 


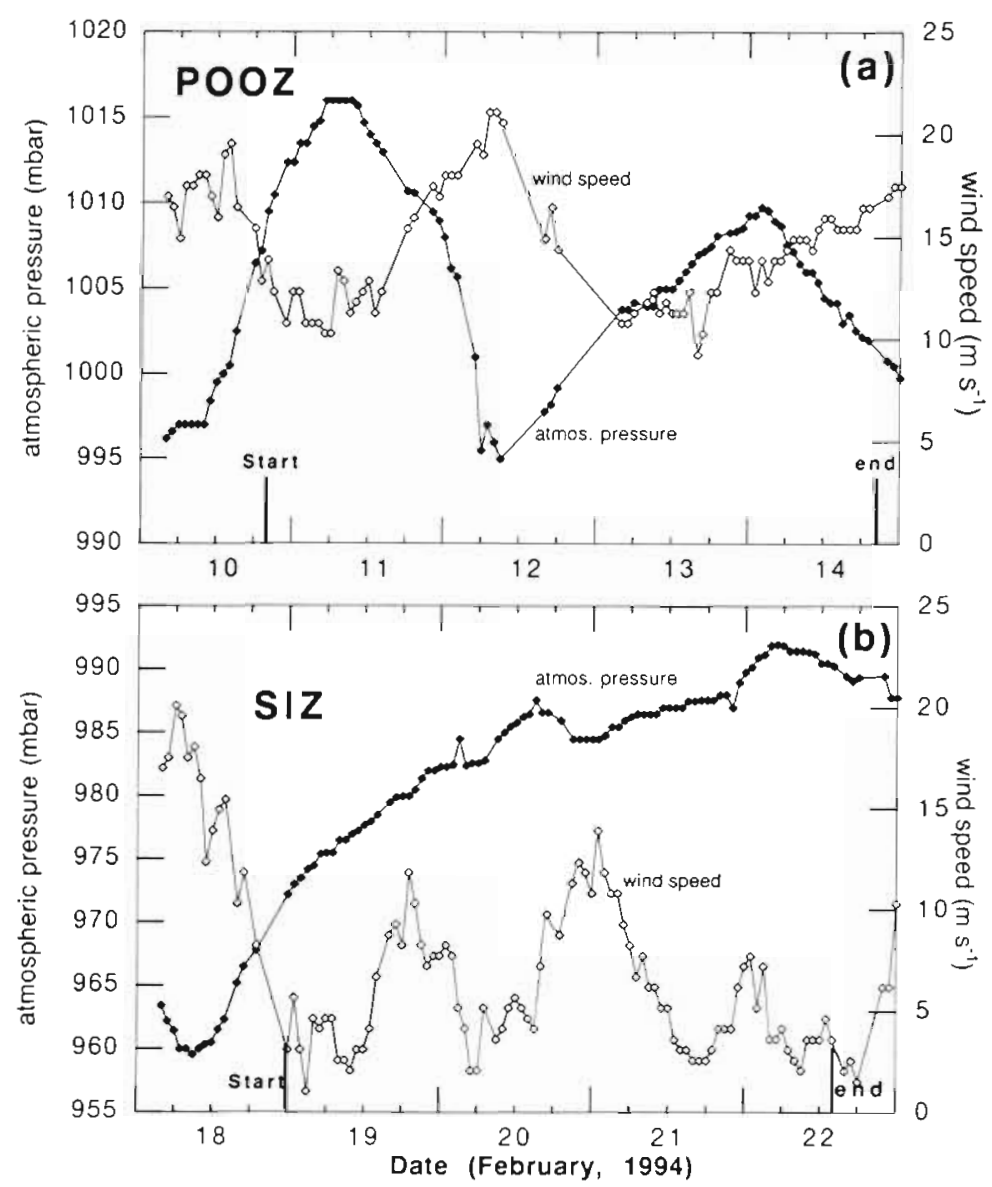

Fig. 2. Hourly variations of atmospheric pressure and wind speed over (a) the POOZ and (b) the SIZ. Vertical bars in bold correspond to the starting and ending time of the export flux series

investigate the differences in planktonic communities with the change in hydrographic features. The vertical distribution of the different compounds measured at Stn 13 (Area 3) is shown in Fig, 4a, b.
Pigments were uniformly distributed throughout the euphotic zone $11 \%$ of incident irradiance), the depth of which was about $80 \mathrm{~m}$ in the POOZ (Cailliau et al. 1997). Concentrations decreased rapidly below $100 \mathrm{~m}$ (Fig. 4a). The value of the HEX to BUT ratio (prymnesiophytes vs pelagophytes) was about 3 in the upper $100 \mathrm{~m}$ and was more variable ( 2 to 4 ) below this depth (Fig. $5 \mathrm{c}$ ). The value of the FUCO to (HEX + BUT) ratio (diatoms vs nanoflagellates) was equal to 0.6 in the upper $100 \mathrm{~m}$ and increased up to a value of 3 at $200 \mathrm{~m}$ depth (Fig. 5b). The $F_{\mathrm{p}^{-}}$ ratio (microphytes vs total phytoplankton) was equal to 0.35 in the upper $100 \mathrm{~m}$ and increased up to 0.75 at $200 \mathrm{~m}$ depth (Fig. 5a). Levels of chl a, FUCO and HEX were about $20 \%$ higher at Stn 13 than at Stn 3, while levels of BUT were $60 \%$ higher (data not shown). The transition from Area 2 to Area 3 resulted in a significant change of the structure of phytoplankton towards an increase of the relative importance of the nanoplanktonic pool (data not shown). The very low concentrations of peridinin, alloxanthin and zeaxanthin measured suggested that dinoflagellates, cryptophytes and prokaryotes were not major components of the phytoplankton biomass (data not shown). Small amounts of phaeopigments were found in the water colum (data not shown); the integrated concentrations of phaeophorbides and phaeophytins never exceeded $0.45 \mathrm{mg} \mathrm{m}^{-2}$, which represented about $1.5 \%$ of the chl a standing stock (Cailliau et al. 1997).

In the upper $100 \mathrm{~m}$, about $75 \%$ of DMSPp was found in the size fraction $<10 \mu \mathrm{m}$ (Fig. $4 \mathrm{~b}$ ). Below $100 \mathrm{~m}$,
Fig. 3. Mean vertical profiles of (a) potential temperature, (b) salinity and (c) sigma-theta in the upper $200 \mathrm{~m}$ at the 2 sites
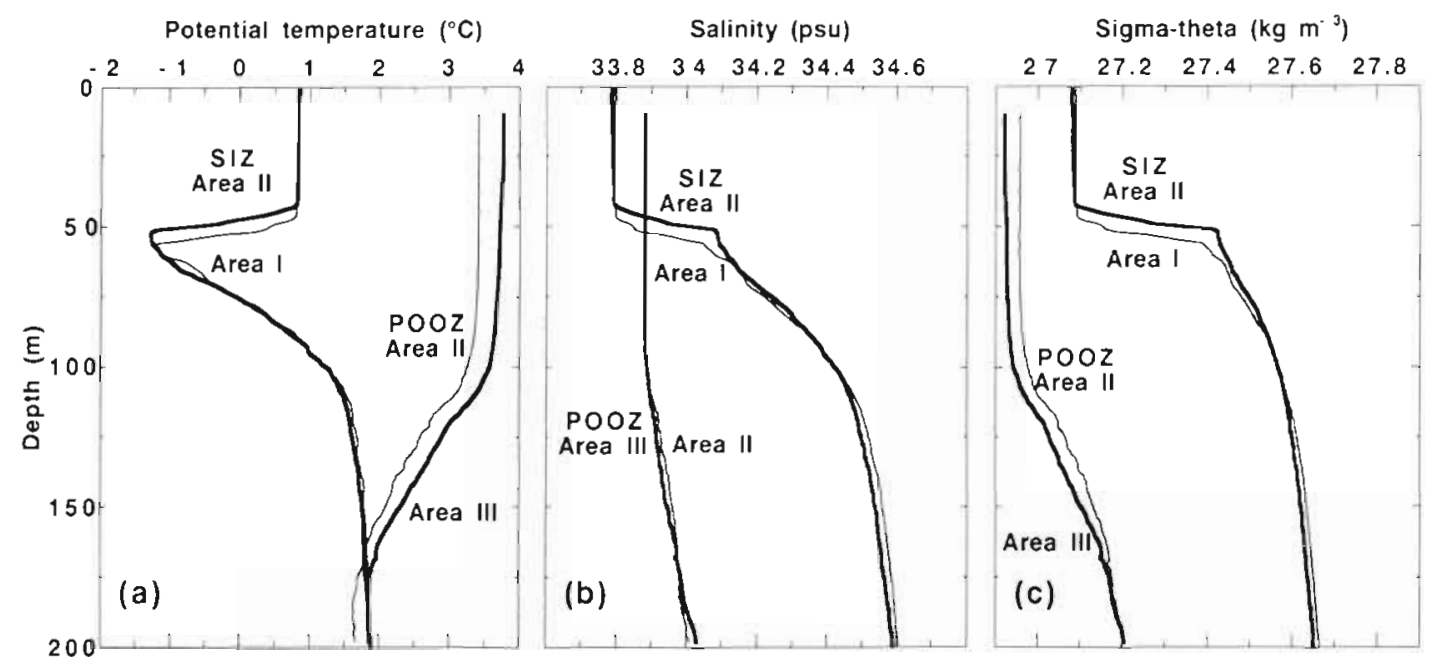
DMSPp predominated in the $>10 \mu \mathrm{m}$ size fraction. Mean mixed layer levels of DMSPp were about $12 \%$ higher at Stn 13 than at Stn 3. However, the transition from Area 2 to Area 3 resulted in a significant change of the size fractionation of DMSPp towards an increase in the relative importance of the nanoplanktonic pool (data not shown).

TPC exhibited a subsurface maximum at 80 and $100 \mathrm{~m}$ depth (Fig. 4b). Mean TPC levels and the TPC vertical distribution were not affected by the transition from Area 2 to Area 3.

Suspended particles devoted to lipid analyses were collected at Stn 3 only (Table 1). The vertical distribution of TL (2.7 to $25 \mathrm{\mu g} \mathrm{l}^{-1}$ ) (Fig. 6a) in the upper $100 \mathrm{~m}$ exhibited a subsurface minimum located at $60 \mathrm{~m}$. Deeper than $100 \mathrm{~m}$, a subsurface maximum was observed at $150 \mathrm{~m}$ depth, corresponding to the base of the pycnocline. The lipid-to-TPC ratio was in the range 2 to $28 \%$ (Fig. 6b). In the upper $100 \mathrm{~m}$, lipids represented $10 \%$ of TPC on average. Thus the suspended particles at this station have an overall low lipid content. Chloroplast lipids (AMPL) and ST represented on average 28 and $13 \%$ of the $T L$, respectively (Fig. $6 \mathrm{c}, \mathrm{d}$ ).

Microplankton reserves (TG) fluctuated in the range 0 to $16 \%$, thus around values reparted for healthy growing phytoplankton (data not shown). Changes in the lipid composition of suspended particles were noticeable at the pycnocline (120 to $150 \mathrm{~m}$ ). At these depths,

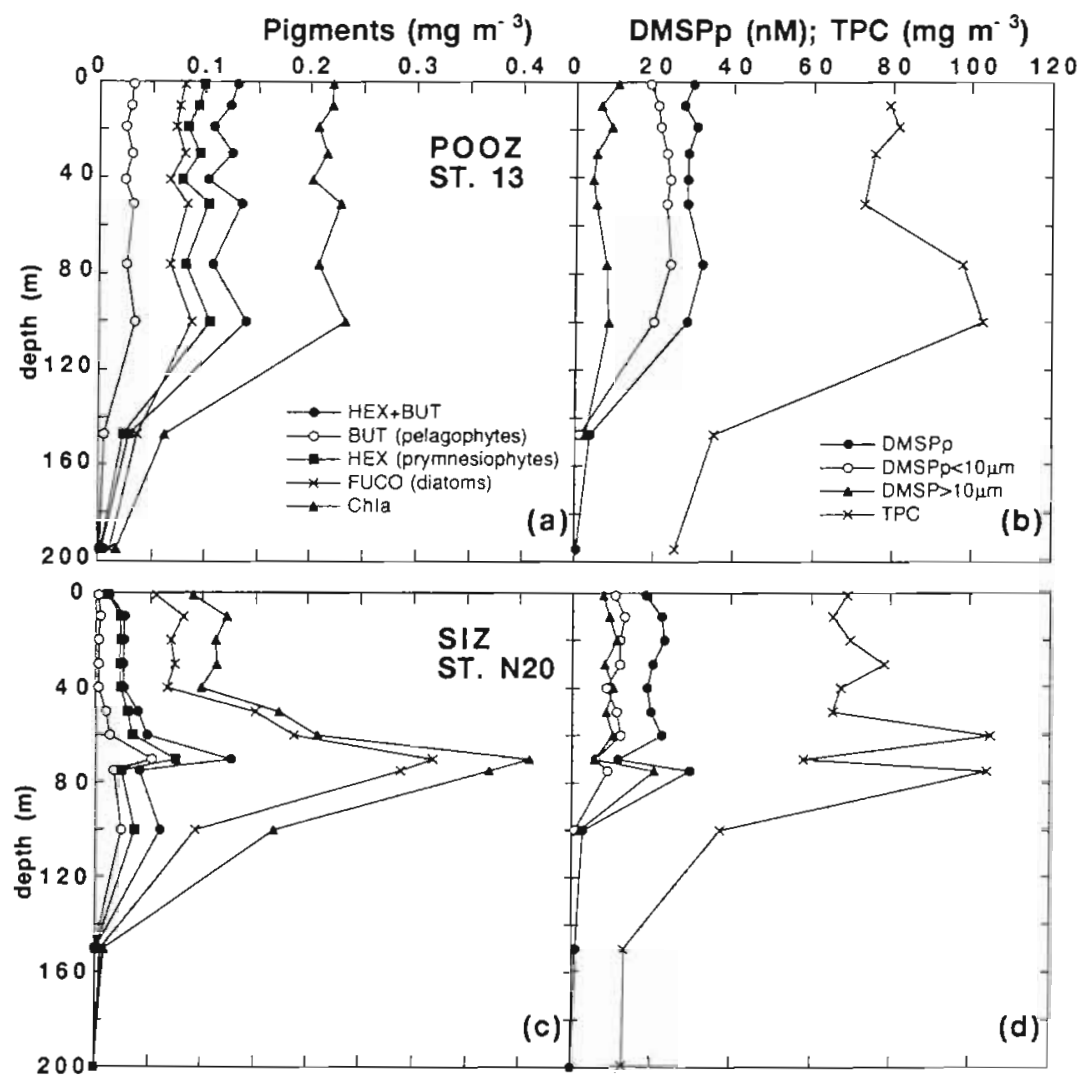

Fig. 4. Depth profiles of chlorophyll $a$ and pigments with $(\mathrm{a}, \mathrm{c})$ chemotaxonomic significance, and $(b, d)$ whole and fractionated DMSPp and TPC in the upper $200 \mathrm{~m}$ at the 2 sites

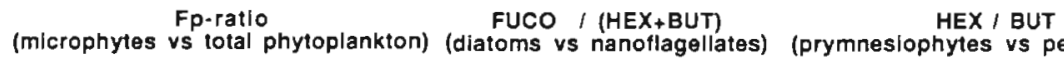

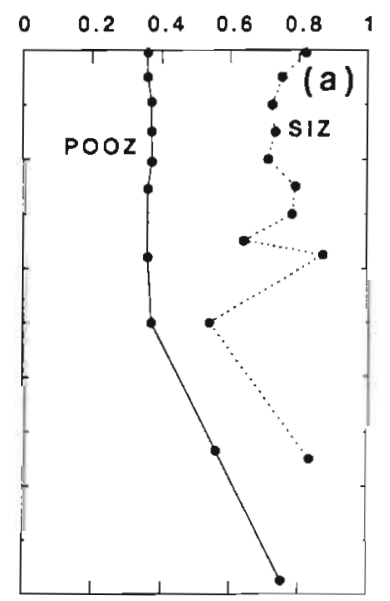

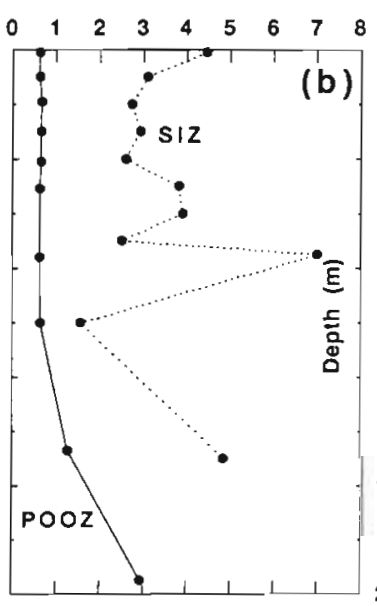

suspended particles were enriched in zooplankton reserves (WE, 20 to $23 \%$, Fig. 6e). The LI (Fig. 6f), which was high in the upper $40 \mathrm{~m}$ (0.65 and 1.3), then stabilized below $40 \mathrm{~m}$ at 0.45 on average. Its mean value in the upper $100 \mathrm{~m}$ was 0.6 .

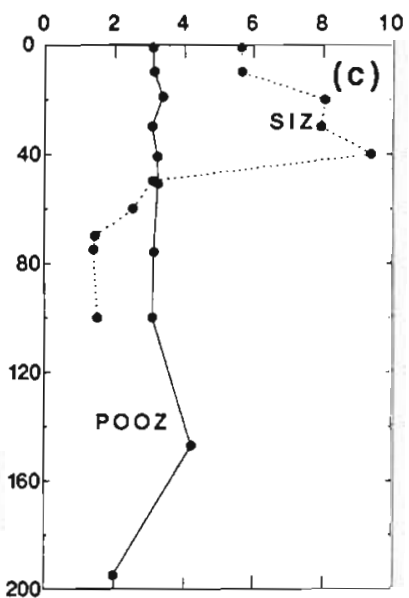

Fig. 5. Selected ratios of pigments with chemotaxonomic significance at the 2 sites (SIZ, POOZ): (a) $\mathrm{F}_{\mathrm{p}^{-}}$ ratio (microphytoplankton vs total phytoplankton), (b) FUCO-to-HEX + BUT (diatoms vs nanoflagellates), (c) HEX-to-BUT (prymnesiophytes vs pelagophytes) 

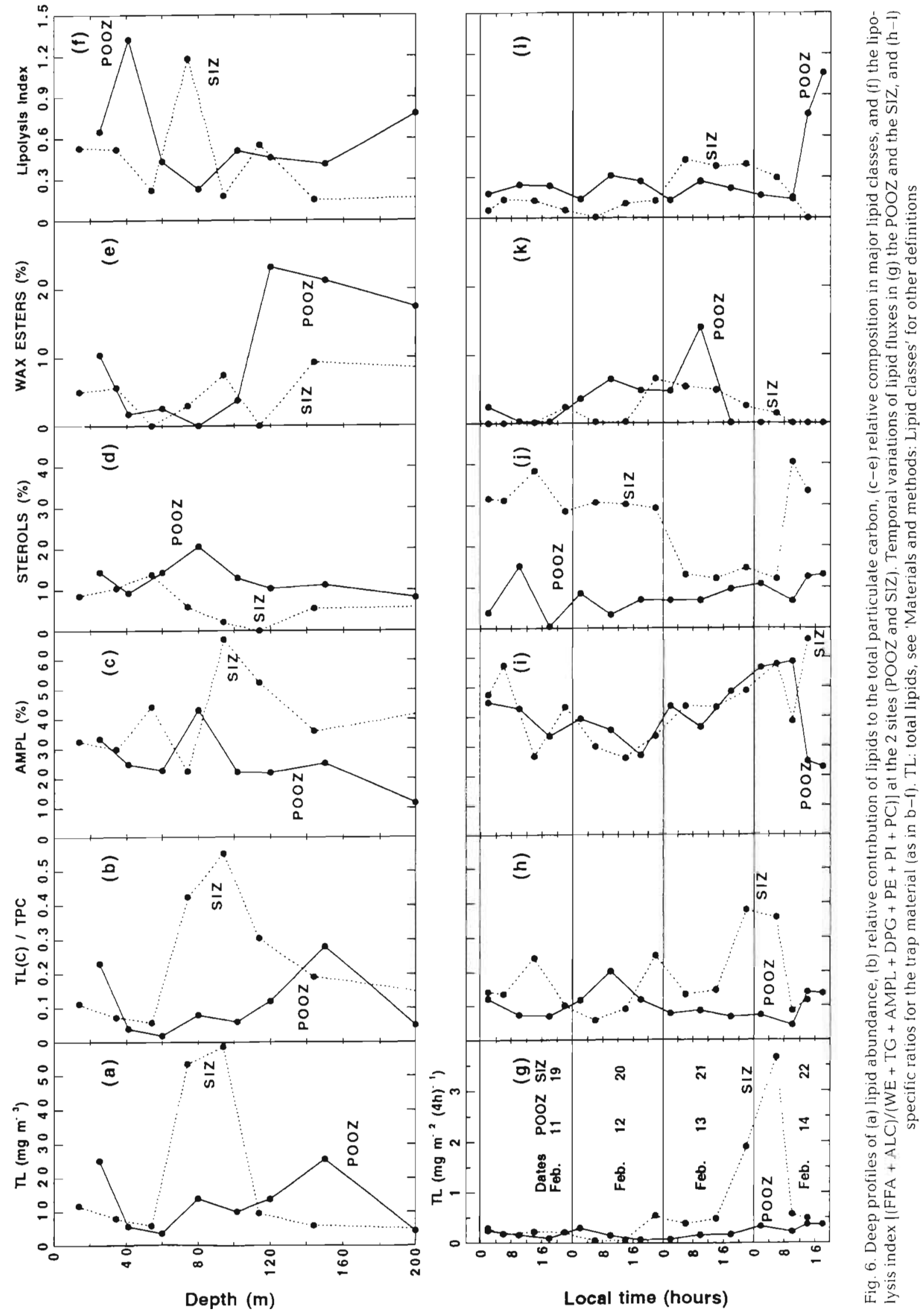
$\operatorname{SIZ}$

One important characteristic of the SIZ is the existence of a deep pigment maximum (DPM) with values of chl a

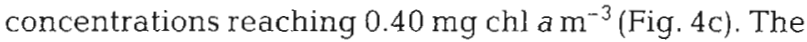
depth of the DPM was about $70 \mathrm{~m}$, near the base of the euphotic zone. The pigment signatures revealed a dominance of diatoms, especially at the DPM (data not shown). The FUCO-to-(HEX+BUT) ratio (diatoms vs nanoflagellates) was in the range 2 to 7 (Fig. $5 \mathrm{~b}$ ) and was equal to 3.5 on average. The mean $F_{p}$-ratio was 0.75 (Fig. 5a). The HEX-to-BUT ratio (prymnesiophytes vs pelagophytes) was in the range 6 to 10 in the upper $40 \mathrm{~m}$ and decreased markedly below this depth to reach an average value of 2 at the depth of the DPM (Fig. 5c). A subsurface maximum of peridinin was detected at $80 \mathrm{~m}$ depth (data not shown). Very small amounts of chl a degradation products (less than $0.4 \mathrm{mg}$ phaeopigments $\mathrm{m}^{-2}$ ) were measured, with dominance of phaeophytin on phaephorbide (Cailliau et al. 1997).

DMSPp in the size range $<10 \mu \mathrm{m}$ slightly dominated in the upper $60 \mathrm{~m}$ (Fig. 4d). Below $60 \mathrm{~m}$, and especially at $80 \mathrm{~m}$ depth, DMSPp dominated in the fraction $>10 \mu \mathrm{m}$.

Samples for TPC determination were collected on a daily basis at the SIZ (Stns N19, N20, N21 and 23) along the drifter trajectory (Table 1). The 4 profiles show TPC levels in the upper $50 \mathrm{~m}$ to be roughly constant and to sharply decrease below $80 \mathrm{~m}$ depth as shown in Fig. $4 \mathrm{~d}$. In between these depths, the situations were much more contrasted. The peculiar shape of the subsurface maximum of TPC at Stn N20 (Fig. 4d) cannot result from a sampling artifact because the vertical structure of TPC at Stn N21 was comparable, although the resolution of the peaks of TPC at Stn N21 was lower than at Stn N20. There was a broad subsurface maximum of TPC at Stn 23 and no TPC maximum at Stn N19.

$\mathrm{TL}$ in the range 5.6 to $59 \mu \mathrm{g} \mathrm{l}^{-1}$ exhibited a strong subsurface maximum at the DPM (75 m) and just below (95 m, Fig. 6a). ST represented on average $6 \%$ of the TL but were almost absent at the DPM (Fig. 6d). Conversely, AMPL represented more than $35 \%$ (on average) of the $\mathrm{TL}$ and predominated at $95 \mathrm{~m}$ (Fig. 6c). Strong increases in the lipid-to-TPC ratio took place at these depths (Fig. 6b). Indeed, the lipid-to-TPC ratio varied from $6-11 \%$ in the upper $60 \mathrm{~m}$ to $42-55 \%$ at $75-95 \mathrm{~m}$, decreasing steadily below these depths. Zooplankton reserves were low in the upper $150 \mathrm{~m}$ (Fig. 6e). The LI was on average equal to 0.5 and peaked at the DPM (Fig. 6f).

\section{Export fluxes of nitrogen and related compounds}

Ranges and contrasts in composition and lability of the sedimented material

Fluxes of TPC, pigments, DMS(P) and lipids expressed in units of weight $\mathrm{m}^{-2} 4 \mathrm{~h}^{-1}$ are shown in Fig. 7 plotted versus the PON fluxes, PON being a labile component of the phytoplanktonic material. This figure provides a way to visualise (1) the dynamics of the fluxes (ranges of the specific fluxes and degree of covariation of the fluxes with the PON ones), and (2) the
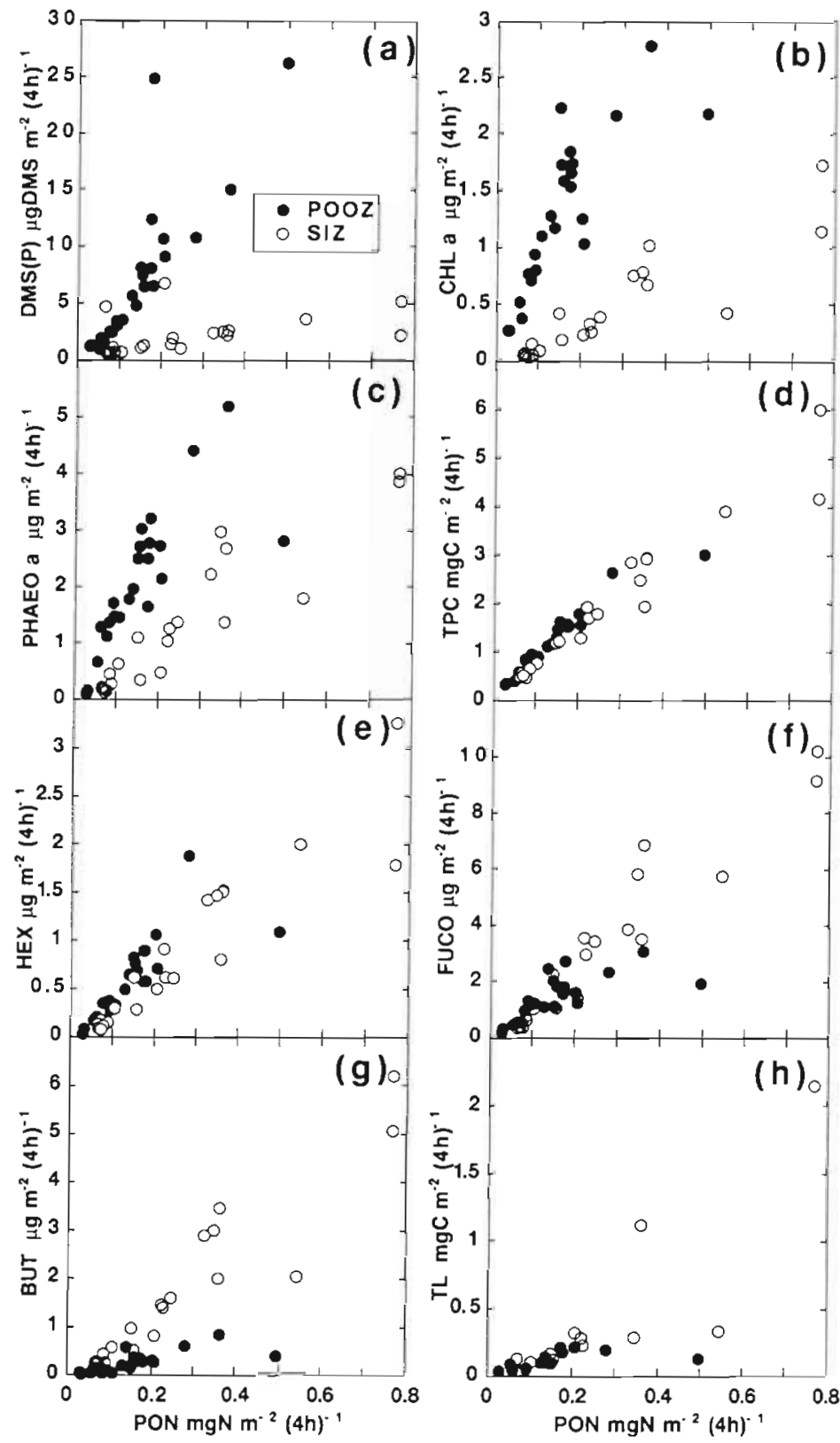

Fig. 7. Fluxes of DMS(P) and related compounds versus PON fluxes at the POOZ and the SIZ 
spatial variations (POOZ vs SIZ) in the composition of the sedimenting material in the Indian sector of the Southern Ocean and the contrasts in lability between the compounds. Minimum and maximum hourly fluxes of PON were about twice as high in the SIZ than in the POOZ (Fig. 7). Fluxes of BUT (of pelagophytes) and TL were markedly higher in the SIZ than in the POOZ. Conversely, DMS(P) fluxes were much more intense in the POOZ than in the SIZ. Although we observed 2 situations in the SIZ and 1 case in the POOZ where DMS(P) was strongly enhanced in the trap material relative to PON, the downward fluxes of $\mathrm{DMS}(\mathrm{P})$ and PON were linearly correlated even in the SIZ (Fig. 7a). The other fluxes were also significantly correlated with PON. The DMS(P)-to-PON ratio is about 5 times lower in the SIZ than in the POOZ. The paucity in DMS(P) of the material collected in the SIZ is striking as the enhancement in BUT. The case of DMS(P) resembles the case of chl a (Fig. $7 \mathrm{~b}$ ) much more than of the other compounds (Fig. $7 \mathrm{C}$ to $\mathrm{h}$ ).

\section{Daily variations of fluxes and selected ratios}

POOZ. The TPC and PON fluxes (Fig. 8c) exhibited maxima during the night and early morning (time interval 0 to $8 \mathrm{~h}$ ) and minima during the day, except for the last day when the fluxes peaked later in the morning (time interval 8 to 12 h). Levels of phaeophytin (the less degraded form of chl a) and pyrophaeophorbide (the most degraded form of chl a) were the dominant forms of phaeopigments (Fig. 8a). The average chl ato-phaeopigment ratio was equal to 0.7 . The ratio was minimum at night during the time interval 0 to $4 \mathrm{~h}$ and presented a peak during the day of Day 12 (Fig. 9a). The mean HEX-to-BUT ratio (prymnesiophytes vs pelagophytes) was 3.1, and no clear daily variations were observed (Fig. 9b). Also shown is the mean HEXto-BUT ratio in the upper $200 \mathrm{~m}$ in the $\mathrm{POOZ}$. The FUCO-to-(HEX+BUT) ratio (diatoms vs nanoflagellates) was in the range 1.8 to 3.2 during the first half of the series, then decreased in the range 1 to 1.7 during the second half of the series (Fig. 9d). The $T_{p}$-ratio (PERI+FUCO vs all diagnostic pigments expressed in terms of fluxes) also showed a temporal decrease (Fig. 9c). The mean $F_{p}$-ratio calculated in the upper $100 \mathrm{~m}$ is reported in Fig. 9c.

The temporal resolution of the lipid time series was half the resolution of other parameters except for the last $12 \mathrm{~h}$. The highest lipid fluxes were observed during the last day of the series (Fig. $6 \mathrm{~g}$ ). Lipids accounted for about 5 to $20 \%$ of TPC fluxes (Fig. 6h). The lipid content in the POOZ well reflected the average lipid content of the suspended particles of the water column (Fig. 6b). The membrane lipids, AMPL, accounted for the major fraction ( $45 \%$ in average) of lipid fluxes (Fig. 6i). AMPL fluxes were significantly correlated to the POC flux and exhibited maxima in the night (time
Fig. 8. Temporal variations of specific phaeopıgments and TPCPON fluxes during the two 4 d time series. Note that the PON fluxes have been multiplied by 10
POOZ

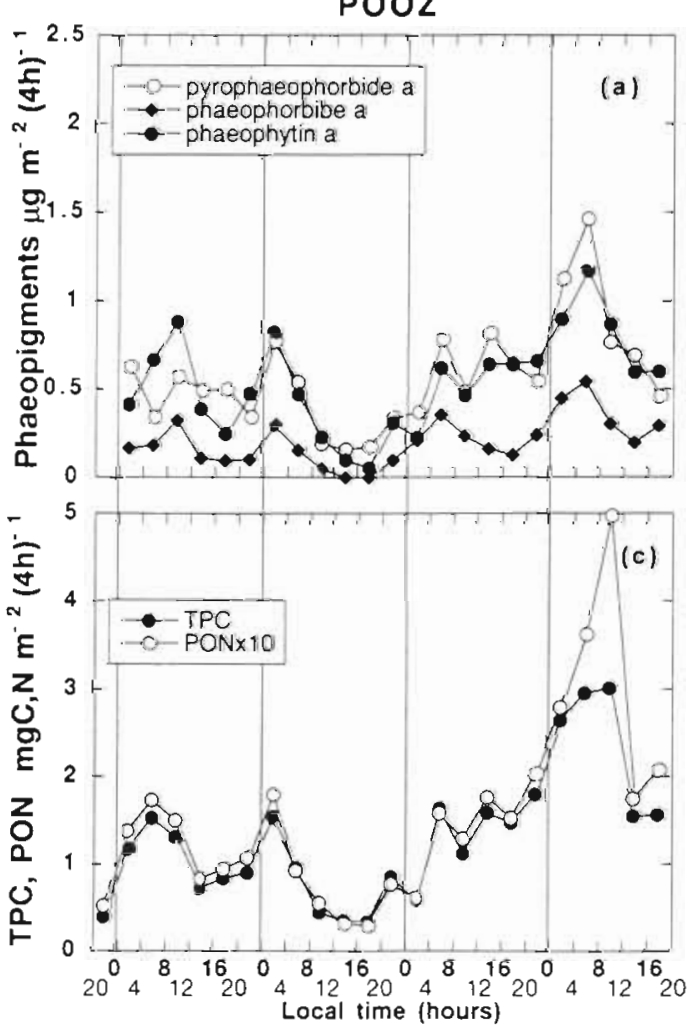

SIZ

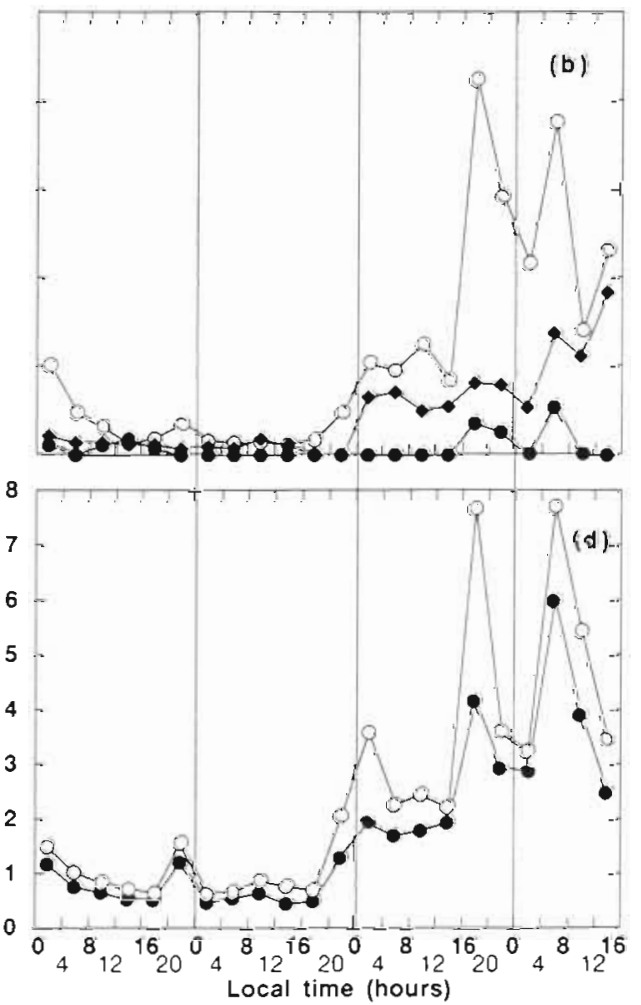




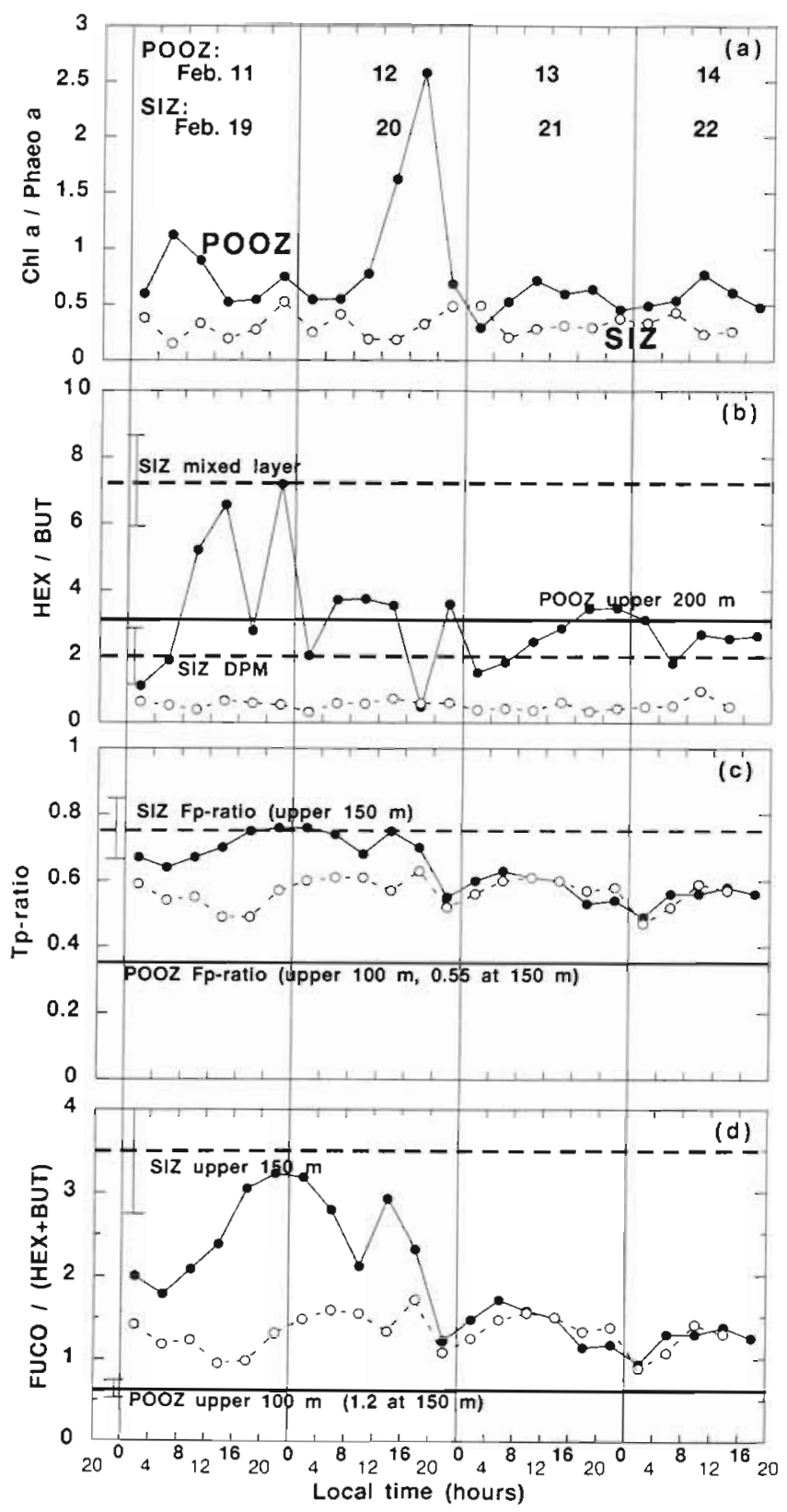

Fig. 9. Chl a-to-phaeopigments ratio and selected ratios of pigments with chemotaxonomic significance during the two $4 \mathrm{~d}$ times series. The solid lines and closed symbols refer to the POOZ and the hatched lines and open symbols to the SIZ. Error bars on the left side of the panels correspond to $1 \mathrm{SD}$

interval 0 to $4 \mathrm{~h}$ ) of Days 11, 12 and 14 (data not shown). ST, another important component of microalgae membranes, amounted to $7-8 \%$ on average of TL (Fig. 6j). When WE were present they accounted for about $10 \%$ of TL (Fig. $6 \mathrm{k}$ ). During most of the time, the LI remained remarkably stable and low (about 0.2 ). However, it strongly increased toward the end of the series (Fig. 6l).
SIZ. During the first half of the time series in the SIZ we observed slight daily variations of pigments and TPC or PON with nocturnal maxima and daytime minima (Fig. 8b,d). The second part of the series exhibited a strong increase of pigment and TPC or PON export. Although the diel periodicity was less noticeable, a maximum occurred during the late afternoon and night of February 21, preceded and followed by lower fluxes in the late morning on February 21 and 22, respectively. Fluxes of phaeopigments indicated a dominance of the most degraded form of chl a (pyrophaeophorbide), while fluxes of phaeophytin were negligible (Fig. 8b). The HEX-to-BUT ratio (prymnesiophytes vs pelagophytes) was lower than unity (Fig. 9b, 0.5 on average). FUCO fluxes slightly dominated fluxes of HEX+BUT, the FUCO-to-(HEX+BUT) ratio (diatoms vs nanoflagellates) being equal to 1.2 on average (Fig. 9d). The mean $T_{\mathrm{p}}$-ratio in the SIZ was constant at 0.55 (Fig. 9c).

The temporal resolution of the lipid time series was half the temporal resolution of other parameters except for the last $12 \mathrm{~h}$ (Fig. 6). Lipids accounted for about 6 to $38 \%$ of carbon fluxes. During the first part of the series, the TL-to-TPC ratio fluctuated with high amplitude around a mean value of 0.2 (Fig. 6h), about twice higher than the ratio characterising the suspended matter of the mixed layer but markedly lower than the ratio at the DPM. Associated with the strong increase in TPC and lipid fluxes observed during the second half of the time series was also an important increase of the lipid-to-TPC ratio (Fig. 6h) and of the LI (Fig. 6l). Both ratios went up to 0.4. AMPL and ST accounted for the major lipid fraction throughout the time series. The contribution of ST, was remarkably higher $25 \%$ on average) than in the POOZ. Little spatial variability was observed for AMPL as for WE.

\section{DISCUSSION}

\section{Scale of Iability of the sedimented material}

The normalisation of the flux of the various markers to the flux of PON (Fig. 7) enables the visualisation of differences, especially in their lability. Indeed, the correlations we have observed are a strong indication of the phytoplanktonic origin of the sedimented material. Since HEX, BUT and FUCO are the dominant diagnostic pigments throughout the water column and are highly correlated with chl a (Fig. 4), one would have expected to measure similar spatial differences for this set of pigment-to-PON ratios in the sedimented material. Conversely, the little spatial differences in the HEX-and FUCO-to-PON ratios, contrast with the depletion of chl a in the SIZ, and the corresponding 
enhancement in BUT of pelagophytes, which are autotrophs. We strongly believe that the contrast in the spatial distribution of pigments originates from their distinct labilities, with chl a being the most labile among the set of pigments. The case of DMS(P) resembles the case of chl $a$ (Fig. $7 \mathrm{~b}$ ) much more than of the other compounds (Fig. $7 \mathrm{C}$ to h). This provides the first field evidence that DMSP and chl a have a similar lability when processed into sedimenting detrital material.

A well-known production pathway of detrital material is zooplankton grazing. According to Head \& Harris (1996), when chl $a$ is ingested by copepods, its degradation goes via one of 2 pathways: one leads to phaeopigment formation and the other to colourless residues. The degrees of chl a destruction by copepods typically are between 20 and $100 \%$ (Head \& Harris 1996). On the basis of their findings Head \& Harris (1996) would caution that measurements of ingestion rates derived using the gut fluorescence method which ignore chlorophyll destruction are fundamentally flawed. Because faecal pellets do not strongly leak pigment and DMSP over a period of $24 \mathrm{~h}$ (Head \& Harris 1996, Kwint et al. 1996), a maximum time for the faecal pellets to reach the sediment trap according to the observed diel periodicity of fluxes (Fig. 8), the trap content should reflect the faecal pellet content which derives from the zooplankton gut content. Thus we have serious reserves about the method which uses the DMSP gut content for the determination of zooplankton grazing activity (Kwint \& Kramer 1996), and which ignores DMSP destruction.

\section{Selective sedimentation of phytoplankton communities}

Following Cailliau et al. (1997), the taxon-specific pigments well document the abundance, composition and fate of phytoplankton during the late austral summer 1994. At both sites, the dominant phytoplanktonic organisms were diatoms and nanoflagellates (Cailliau et al. 1997, Fiala et al. 1998). The species composition measured by microscopic cell counting and carbon biomass conversion (Fiala et al. 1998) was in good agreement with the chemotaxonomic analysis of phytoplankton distribution (Cailliau et al. 1997) in the Indian sector of the Southern Ocean, except for the role played by cryptophytes. Indeed, former authors concluded that cryptophytes accounted for a major fraction of pico- and nanophytoplanktonic biomass at stations in the vicinity of site A01 (POOZ). On the contrary, Cailliau et al. (1997) suggested that cryptophytes were not major components of the phytoplankton biomass because alloxanthin, their specific pigment, levels were very low.
The origin of the discrepancy is unclear. The relative contribution of diatoms to total autotrophic biomass was about twice as high in the SIZ than in the POOZ. This result is consistent with the observations of Fiala et al. (1998), who used size fractionation of particulate chl a to investigate the contribution of the phytoplanktonic communities. The relative distribution of DMSPp between the nanoplanktonic and the microplanktonic groups followed the same trend. In the POOZ, the transition from Area 2 to Area 3 resulted in an increased contribution of the nanoplanktonic pool of DMSPp $(<10 \mu \mathrm{m})$ to total DMSPp in the upper $100 \mathrm{~m}$ (from 65 to $75 \%$ ). In both cases nanoplanktonic DMSPp predominated. In the SIZ, the nanoplanktonic pool of DMSPp accounted for only $55 \%$ of total DMSPp in the upper $60 \mathrm{~m}$ as was chl a in the study of Fiala et al. (1998) in the upper $100 \mathrm{~m}$. These results show that DMSPp at both sites has a strong phytoplanktonic origin and that diatoms are a significant source of DMSPp in the surface waters of the Indian sector of the Southern Ocean. They confirm previous observations carried out in the Pacific and Atlantic sectors of the Southern Ocean (Turner et al. 1995, Meyerdierks et al. 1997). At the depth of the DPM, DMSPp predominated in the microplanktonic pool (Fig. 4d). The maxima of DMSPp $>10 \mu \mathrm{m}$, TPC and peridinin of dinoflagellates (data not shown) at $75 \mathrm{~m} \mathrm{Co}$ incided. Thus, when dinoflagellates are present at high carbon biomass levels, their contribution to the DMSPp appear to overwhelm the contribution of diatoms.

In the POOZ, the comparison of 2 ratios estimated from phytoplankton-specific pigment signatures well illustrates the selective exportation of organic material from diatoms out of the photic zone: the $F_{\mathrm{p}}$-ratio, which represents the contribution of microphytoplankton (here essentially diatoms) to the total autotrophic biomass and calculated in the upper $100 \mathrm{~m}$ (0.35), and the $T_{p}$-ratio, which represents the contribution of microphytoplankton to the total autotrophic fluxes and calculated in the sediment traps ( 0.60 on average), were radically different (Fig 9c). Thus at Site A01 (POOZ), dominated by flagellates and a 'regenerated production' regime (Semeneh et al. 1998), the export was typical of a 'new production' regime since diatoms were essentially exported. However, in the POOZ at the depth of the pycnocline (about $150 \mathrm{~m}$ ), where the chl a level was about a fourth of the surface water levels, the $F_{\mathrm{p}}$-ratio was close to the $T_{\mathrm{p}}$-ratio observed towards the second half of the time series (Fig. 9c). Similarly, the TL-to-TPC ratio peaked at $150 \mathrm{~m}$ and increased in the trap at the end of the time series. It is thus possible that the material which sedimented at $200 \mathrm{~m}$ in the POOZ would originate from the pycnocline. At this depth, zooplankton reserves were well charaterised from lipid analysis (WE, Fig. 6e). Nevertheless, the material sampled during the first half of the series had a distinct sig- 
nature and its richness in diatoms cannot be accounted for by the material located at the pycnocline. The quantitative importance of non-degraded chl $a$ and pheophytin a found in the traps in the POOZ (Fig. 9a) indicated that flux of the particulate organic material out of the photic zone could be due to mass sinking of diatoms, repackaging of particles and physical transport (e.g. downwelling) (Michaels \& Silver 1988, Legendre \& Le Fèvre 1989).

The dominant phytoplankton in the SIZ (mainly diatoms) was typical of a 'new production' regime while the autotrophic community was largely based on 'regenerated production' according to the $f$-ratio values (0.35, Semeneh et al. 1998). Export in this station reflected more the production regime than the phytoplanktonic composition. Indeed, the comparison of the $F_{\mathrm{p}}$-ratio $(0.75$ on average in the upper $150 \mathrm{~m})$, and the $T_{p}$-ratio ( 0.55 on average) (Fig. 9c), indicates a selective exportation of organic material from nanoflagellates (particularly pelagophytes). The strong increase in the proportion of BUT (pelagophytes) in the sediment trap material $(200 \mathrm{~m})$ with average HEX-to-BUT ratio (prymnesiophytes vs pelagophytes) equal to 0.5 cannot be explained only from a preferential sedimentation of material from the DPM because the HEX-to-BUT ratio at the DPM $(80 \mathrm{~m})$ is equal to 2 on average (Fig. 9b). We should rather invoke a process of selective sedimentation of pelagophytes to reach such low values in the trap material, even though a preferential degradation process between HEX and BUT cannot be put aside. In the lipid fraction, the ST contribution to the trap material was much higher at this site than in the POOZ (Fig. 6j). To our knowledge, there is no study in the literature which evidences that ST as a whole class are more important in the lipid spectra of nanoflagellates than in other phytoplankton groups. However, the enrichment with total ST of sediment trap material was observed similarly in the Mediterranean Sea (Central Ligurian Sea) during a time series experiment when flagellates increased their biomass over diatoms in the water column above the drifting traps (Goutx \& Striby 1997). It is thus probable that, in comparison with Site A01 (POOZ), increasing participation of ST to the total lipid flux in the SIZ relates to the preferential exportation of the flagellate biomass. However, we cannot exclude the potential role of the export pathways (zooplankton species for example). Moreover, most of the time, the lipid-to-TPC ratio of the trap material was not as high as at the depth of the DPM (Fig. 6b,h), suggesting that the planktonic material with highest lipid-to-TPC ratios did not sediment preferentially. The preferential sedimentation of material from the DPM occurred as an episodic event during the night of February 21-22 (Fig. 6h,i).

\section{Daily variations of fluxes}

Daily variations of fluxes have been highlighted in the past from deployments of camera or sediment trap systems adopting a high temporal resolution of a few hours (Welschmeyer et al. 1984, Lampitt et al. 1993. Corn et al. 1994). Lampitt et al. (1993), by using a camera system deployed at a depth of $270 \mathrm{~m}$ in the Atlantic Ocean at $47^{\circ} \mathrm{N}$, observed that marine snow particles exhibited strong diel variability, with volume concentrations up to 3 times higher in late morning than at other times of the day. By measuring DMSP of phytoplanktonic origin from sediment trap samples collected at $200 \mathrm{~m}$ depth, Corn et al. (1994) noted that the investigated 3 contrasting trophic regimes of the tropical northeastern Atlantic Ocean at $20^{\circ} \mathrm{N}$ (oligotrophy, mesotrophy and eutrophy) exhibited similar strong diel cycles, the nocturnal $\mathrm{DMS}(\mathrm{P})$ fluxes being up to $100-$ fold lower than the daytime. Diel variability of marine snow concentrations and downward fluxes of DMS(P) were tentatively attributed to the activity of the vertically migrating plankton and nekton. Measurements of the abundance, community composition and vertical distribution of macroplankton and micronekton carried out by Andersen et al. (1997) in the Northeast tropical Atlantic at $20^{\circ} \mathrm{N}$ further confirmed the interpretations of Corn et al. (1994). Recent model simulations, however, have demonstrated that aggregation theory is able to predict marine snow formation (Kiørboe 1997) and that diel variation of small-scale turbulence during a period of generally light winds is the best candidate to explain the daily cycles of aggregates observed in the sea by Lampitt et al. (1993) (Ruiz 1997). Small-scale turbulence can also generate daily cycles in the sedimentation loss of aggregates which result from variations in their vertical distribution (Ruiz 1996).

In a temperate fjord, Dabod Bay, State of Washington, and using phaeopigments as an indicator of herbivorous zooplankton activity, Welschmeyer et al. (1984) noted an increase up to 29-fold in the downward flux of phaeopigments during hours of darkness, presumably resulting from increased grazing activity (Welschmeyer et al. 1984).

The high temporal resolution (hours) of our study permitted the discovery of diel cycles with nocturnal maxima and daytime minima in the POOZ and the SIZ (Fig. 7) roughly in phase with the observations of Welschmeyer et al. (1984) and in opposition with the observations of Corn et al. (1994) and Lampitt et al. (1993). Since the wind speed was over $10 \mathrm{~m} \mathrm{~s}^{-1}$, the physical conditions for diurnal stratification were not favourable in the POOZ and, consequently, zooplankton is the best candidate to explain these cycles. In the SIZ, on the contrary, low wind speed (1 to $3 \mathrm{~m}$ $\mathrm{s}^{-1}$ ) was observed during the day, increasing markedly 
during the night up to $12 \mathrm{~m} \mathrm{~s}^{-1}$ (Fig. 1b). Thus, turbulence, which presented a high daily variability, and zooplankton activity are both potential candidates to explain the daily cycles in the SIZ. The role of zooplankton is addressed in more detail in the following.

\section{Role of zooplankton grazing}

During ANTARES II, the mean biomass of mesozooplankton in the top $200 \mathrm{~m}$ was similar in the northern station A01 (POOZ) and the southern station A04 (SIZ), but although copepods represented over $95 \%$ of zooplankton assemblages, these communities changed along the latitudinal gradient (Errhif \& Labat pers. comm.). Whereas the medium and large copepod fractions ( 500 to $2000 \mu \mathrm{m}$ ) were dominated by Calanus simillimus, Rhincalanus gigas, Metridia lucens and Pleuromamma robusta in the north, they were mainly composed of Calanus propinquus, Calanoides acutus and Metridia gerlachei in the south. The small size fraction was dominated by Microcalanus pygmaeus and Oithona similis in the SIZ while it included only cyclopoid copepods Oithona spp. in the north. The nocturnal increase of sedimentation may be due to increasing zooplankton grazing activity, the result of the combined effects of diel vertical migration and increasing feeding activity of non-migratory animals. However, swimmers trapped within the sampling jars were rare at both sites, suggesting that no largeamplitude vertical migrations were performed by the Southern Ocean zooplankton. Diel periodicity of copepod behaviour has been studied at the PFZ north of South Georgia in February 1994 (Atkinson et al. 1996). These authors observed that large-amplitude vertical migrations which crossed the thermocline were performed only by $M$. Iucens and $P$. robusta. These organisms were present in the POOZ but considering the low densities observed during ANTARES II (Errhif \& Labat pers. comm.) their gut flux is likely to have been negligible. We thus suggest that the diel cycles in export flux observed in the POOZ were the result of increased feeding activity of non-migratory animals. However, the role of micronektonic component cannot be put aside since euphausiid populations are strong vertical migrators and were present in the POOZ, mainly Euphausia vallentini, E. triacantha and E. frigida. In the SIZ, sedimentation diel periodicity was less obvious than in the POOZ and the role played by zooplankton is better evidenced through the high concentrations of pyrophaeophorbide $a$, which is characteristic of zooplankton faecal pellets (Head \& Harris 1992). An explanation for this pigment composition in the $\mathrm{SIZ}$ is that close to $100 \%$ of ingested chl a was degraded during zooplankton grazing and virtu- ally no phaeophorbide a or pheophytin a were produced but instead their pyrolized derivatives (Head \& Harris 1992). It is worth noting that mesozooplankton integrated grazing activity estimated by Errhif \& Labat (pers. comm.) was ca 12 times higher in the SIZ than in the POOZ. Moreover, degradation status of organic material noticeable from the $\mathrm{C} / \mathrm{N}$ ratio in the first $50 \mathrm{~m}$ indicated a more recent material actively growing at the SIZ $(\mathrm{C} / \mathrm{N}=6.1 \pm 0.5)$ compared to the POOZ $(8.4 \pm$ 0.4) (see Robins et al. 1995 for comparison). Hence it seems appropriate to observe a higher zooplankton grazing activity in the SIZ than in the POOZ. Notwithstanding, it is still difficult to interpret at this stage the pathways of the pigment and carbon flux because 'measurement of total phaeopigments or even total phaeophorbides will not be unequivocal indices of zooplankton grazing' (Head \& Horne 1993). Differences in the taxonomic composition of the zooplankton might have affected the pigment composition of the grazed material. In fact, the pigment destruction occurring in the guts varies widely according to the species (Head \& Harris 1992), the previous feeding history of the animal (Head \& Harris 1992, 1994), the concentration of food available and consequently the ingestion rate (Head \& Harris 1996). An alternative explanation for the differences in pigment signatures in the POOZ and the SIZ is that the different copepod species and furthermore different euphausiid species resulted in 2 different pigment budgets after the gut digestive process.

In addition to mesozooplankton, microheterotroph grazers might be responsible for a pigment budget at the 2 sites. However, the paucity of literature data about the transformation of pigments and lipid classes through microheterotroph grazing did not allow us to consider its effect on the signatures observed in the traps

From the lipid point of view, Weeks et al. (1993) found a significant relationship between increasing degradation metabolites proportion in the lipid pool (LI) and increasing rates of zooplankton grazing in the North Atlantic. In our study, LI variations were more significant as regards differences in depth than in latitude. LI maxima were observed at selected depths (40 $\mathrm{m}$ in the POOZ, DCM in the SIZ), suggesting that zooplankton fed either at preferential depth (POOZ) and/or on particular phytoplankton assemblages (DCM in the SIZ). In the traps, the increases of Ll seen in February 14 in the POOZ or February $21-22$ at night in the SIZ may indicate the episodic transport of material originating from these depths. In most trap samples, however, LI was lower than in the water column probably because FFA and ALC are more rapidly metabolised than other lipids through bacterial activity during sedimentation. 


\section{CONCLUSION}

In the Indian sector of the Southern Ocean, during late summer 1994 when the production regime was dominated by regeneration, the predominating phytoplanktonic populations were nanoflagellates at the POOZ and diatoms at the SIZ. The downward fluxes of chemotaxonomic pigments neither reflected the water phytoplanktonic composition at both locations nor the production regime at the $\mathrm{POOZ}$ since the organisms sedimenting preferentially at the POOZ were diatoms, and nanoflagellates (pelagophytes) at the SIZ. Accumulation of ST in the trap of the SIZ was a characteristic feature of nanoflagellates dominating the flux. The downward fluxes of several markers exhibited diel variations with maxima during the night and minima during the day. These results indicate that the selective grazing of phytoplankton by zooplankton is an important process to account for the export of organic matter to the deep ocean. We provided the first field evidence of the high lability of DMSP during the sedimentation process which is comparable to that of $\mathrm{chl}$ a.

Acknowledgements. Data presented here were collected during the ANTARES II cruise sponsored by the Institut Français pour la Recherche et la Technologie Polaires, and the CNRSINSU (JGOFS-France program). This is LSCE contribution no. 182. We would like to thank Prof. Paul Tréguer, who was the initiator of the project, and Dr Michel Fiala, who was the chief scientist of this cruise. We are grateful to Yves L'Herrou from the Division Technique of INSU in Brest, who prepared and deployed the sediment traps during ANTARES II. We address special thanks to the captain and crew of the RV 'Marion Dufresne' for their able assistance during this cruise. We thank D. Repeta for the phaeopigment standards provided. Four anonymous referees provided very helpful comments.

\section{LITERATURE CITED}

Andersen V, Sardou J, Gasser B (1997) Macroplankton and micronekton in the northeast tropical Atlantic: abundance, community composition and vertical distribution in relation to different trophic environments. Deep-Sea Res I 44:193-222

Atkinson A, Ward P, Murphy EJ (1996) Diel periodicity of subantarctic copepods: relationships between vertical migration, gut fullness and gut evacuation rate. J Plankton Res $18: 1387-1405$

Bak RPM, Boldrin A, Nieuwland G, Rabitti S (1992) Biogenic particles and nano/picoplankton in water masses over the Scotia-Weddell sea confluence, Antarctica. Polar Biol 12: $219-224$

Belviso S, Buat-Ménard P, Putaud JP, Nguyen BC, Claustre $H$, Neveux J (1993) Size distribution of dimethylsulfoniopropionate (DMSP) in areas of the tropical northeastern Atlantic Ocean and Mediterranean Sea. Mar Chem 44:55-71

Bidigare RR, Iriarte JL, Kang $\mathrm{SH}$, Karentz D, Ondrusek ME, Fryxell GA (1996) Phytoplankton: quantitative and qualitative assessments. In: Ross RM, Quetin LB, Hofmann EE (eds) Foundations for ecological research west of the Antarctic Peninsula, Vol 70. Antarctic Research Series, American Geophysical Union, Washington, DC, p 173-198 Bligh EG, Dyer WJ (1959) A rapid method of total lipid extraction and purification. Can J Biochem Physiol 37:911-917

Boyd PW, Newton PP (1999) Does planktonic community structure determine particulate organic carbon flux in different oceanic provinces? Deep-Sea Res 46:63-91

Buma AGJ, Bano N, Veldhuis MJW, Kraay GW (1991) Comparison of the pigmentation of two strains of the prymnesiophyte Phaeocystis sp. Neth J Sea Res 27:173-182

Cailliau C, Claustre H, Giannino S (1997) Abundance, composition and trophic status of phytoplankton in the Indian sector of the Southern Ocean, during late austral summer, as determined by pigment signatures. Oceanol Acta 20: $721-732$

Cavaletto JF, Vanderploeg HA, Gardner WS (1989) Wax esters in two species of freshwater zooplankton. Limnol Oceanogr 34:785-789

Claustre $H$ (1994) The trophic status of various oceanic provinces as revealed by phytoplankton pigment signatures. Limnol Oceanogr 39:1207-1211

Corn M, Belviso S, Nival P, Vigot A, Buat-Ménard P (1994) Downward flux of particulate dimethylsulfoniopropionate (DMSP) in areas of the tropical open ocean. Oceanol Acta $17: 233-236$

Corn M, Belviso S, Partensky F, Simon N, Christaki U (1996) Origin and importance of picoplanktonic DMSP. In: Kiene RP, Visscher PT, Keller MD, Kirst GO (eds) Biological and environmental chemistry of DMSP and related sulfonium compounds. Plenum, New York, p 191-201

Cullen JJ (1991) Hypotheses to explain high-nutrient, lowchlorophyll conditions in the open sea. Limnol Oceanogr 36:1578-1599

Fiala M, Semeneh M, Oriol L (1998) Size-fractionated phytoplankton biomass and species composition in the Indian sector of the Southern Ocean during austral summer. J Mar Syst 17:179-194

Goutx M, Striby L (1997) Lipids in sediment trap: significance in vertical flux studies. In: Dehairs F, Elskens M, Goeyens $\mathrm{L}$ (eds) Integrated marine system analysis. European network for integrated marine system analysis. Proceedings of the second network meeting (Brussels, May 29-31, 1997). VUB Vrije Universiteit Brusse, Brussels, p 279-297

Goutx M, Gérin C, Bertrand JC (1990) An application of Iatroscan thin-layer chromatography with flame ionization detection - lipids classes of microorganisms as biomarkers in the marine environment. Organic Geochem 16: $1231-1237$

Head EJH, Harris LR (1992) Chlorophyll and carotenoid transformation and destruction by Calanus spp. grazing on diatoms. Mar Ecol Prog Ser 86:229-238

Head EJH, Harris LR (1994) Feeding selectivity by copepods grazing on natural mixtures of phytoplankton determined by HPLC analysis of pigments. Mar Ecol Prog Ser 110:75-83

Head EJH, Harris LR (1996) Chlorophyll destruction by Calanus spp. grazing on phytoplankton - kinetics, effects of ingestion rate and feeding history, and a mechanistic interpretation. Mar Ecol Prog Ser 135:223-235

Head EJH, Horne EPW (1993) Pigment transformation and vertical flux in an area of convergence in the North Atlantic. Deep-Sea Res II 40:329-346

Jacques G (1989) Primary production in the open Antarctic ocean during the austral summer. A review. Vie Milieu 39:1-17

Jacques G (1991) Is the concept of new production-regener- 
ated production valid for the Southern Ocean? Mar Chem 35:273-286

Jacques G, Panouse M (1991) Biomass and composition of size fractionated phytoplankton in the Weddell-Scotia confluence area. Polar Biol 11:315-328

Kattner G (1989) Lipid composition of Calanus finmarchicus from the north sea and the arctic. A comparative study. Comp Biochem Physiol 94B:185-188

Keller MD, Bellows WK, Guillard RRL (1989) Dimethylsulfide production in marine phytoplankton. In: Saltzman E, Cooper W (eds) Biogenic sulfur in the environment. American Chemical Society, Washington, DC, p 167-182

Kiorboe T (1997) Small-scale turbulence, marine snow formation, and planktivorous feeding. Sci Mar 61:141-158

Kwint RLJ, Kramer KJM (1996) A new sensitive tracer for the determination of zooplankton grazing activity. J Plankton Res 18:1513-1518

Kwint RLJ, Irigoien X, Kramer KJM (1996) Copepods and DMSP. In: Kiene RP, Visscher PT, Keller MD, Kirst GO (eds) Biological and environmental chemistry of DMSP and related sulfonium compounds. Plenum Press, New York, p 239-252

Lampitt RS, Hillier WR, Challenor PG (1993) Seasonal and diel variation in the open ocean concentration of marine snow aggregates. Nature 362:737-739

Lancelot C, Billen G, Mathot S (1989) Ecophysiology of phytoplankton and bacterioplankton growth in the Southern Ocean. In: Cachetto S (ed) Belgian scientific research programme on Antarctica. Scientific results of phase one (Oct. 85-Jan. 89). Vol 1: Plankton Ecology. Science Policy of Belgium, Brussels, p 1-97

Legendre L, Le Fève J (1989) Hydrodynamical singularities as controls of recycled versus export production in oceans. In: Berger WH, Smetacek VS, Wefer G (eds) Productivity of the ocean: present and past. Wiley, Chichester, p 49-63

Meyerdierks D, Bolt B, Kirst GO (1997) Spatial and vertical distribution of particulate dimethylsulfoniopropionate (DMSP) during spring in the Atlantic sector of the Southern Ocean. Deep-Sea Res II 44:283-297

Michaels AF, Silver MW (1988) Primary production, sinking fluxes and the microbial food-web. Deep-Sea Res 35: 473-491

Ohman MD (1988) Sources of variability in measurements of copepod lipids and gut fluorescence in the California Current coastal zone. Mar Ecol Prog Ser 42:143-153

Parrish CC (1988) Dissolved and particulate marine lipid classes: a review. Mar Chem 23:17-40

Parrish CC, Wangersky PJ (1987) Particulate and dissolved lipid classes in cultures of Phaeodactylum tricornutum grown in cage culture turbidostats with a range of nitrogen supply rates. Mar Ecol Prog Ser 35:119-128

Parrish CC, Mckenzie CH, MacDonald BA, Hatfield EA (1995) Seasonal studies of seston lipids in relation to microplankton species composition and scallop growth in South Broad Cove, Newfoundland. Mar Ecol Prog Ser 129:151-164

Robins DB, Harns RP, Bedo AW, Fernandez E, Fileman TW, Harbour DS, Head RN (1995) The relationship between suspended particulate material, phytoplankton and zooplankton during the retreat of the marginal ice zone in the Bellinghausen Sea. Deep-Sea Res 42:1137-1158

Ruiz J (1996) The role of turbulence in the sedimentation loss of pelagic aggregates from the mixed layer. J Mar Res 54 : $385-406$

Ruiz J (1997) What generates daily cycles of marine snow? Deep-Sea Res 1 44:1105-1126
Sargent JR (1978) Marine wax esters. Sci Prog Oxford 65: $437-458$

Scharek R, Smetacek V, Fahrbach E, Gordon LI, Rohardt $G_{\text {, }}$ Moore S (1994) The transition from winter to early spring in the eastern Weddell sea, Antarctica: plankton biomass and composition in relation to hydrography and nutrients. Deep-Sea Res 41:1231-1250

Semeneh M, Dehairs F, Fiala M, Elskens M, Goeyens L (1998) Seasonal variation of phytoplankton community structure and nitrogen uptake regime in the Indian Sector of the Southern Ocean. Polar Biol 20:259-272

Turner SM, Nightingale PD, Broadgate W, Liss PS (1995) The distribution of dimethyl sulphicle and dimethylsulphoniopropionate in Antarctic waters and sea ice. Deep-Sea Res II 42:1059-1080

Vaulot D, Birrien JL, Marie D, Casotti R, Veldhuis MJW, Kraay GW, Chrétiennot-Dinet MJ (1994) Morphology, ploidy, pigment composition, and genome size of cultured strains of Phaeocystis (Prymnesiophyceae). J Phycol 30: $1022-1035$

Volkman JK (1986) A review of sterol markers for marine and terrigenous organic matter. Org Geochem 9:83-99

Volkman JK, Hallegraeff GM (1988) Lipids in marine diatoms of the genus Thalassiosira: predominance of 24-methylenecholesterol. Phytochemistry 27:1389-1394

Volkman JK, Jeffrey SW, Nichols PD, Rogers GI, Garland CD (1989) Fatty acids and lipid composition of ten species of microalgae used in mariculture. J Exp Mar Biol Ecol 128: $219-240$

Volkman JK, Kearney PS, Jeffrey SW (1990) A new source of 4-methyl sterols and 5a stanols in sediments: prymnesiophyte microalgae of the genus Pavlova. Organic Geochem $15: 489-497$

Volkman JK, Barret SM, Dunstan GA, Jeffrey SW (1993) Geochemical significance of the occurrence of dinosterol and other 4-methyl sterols in a marine diatom. Org Geochem 20:7-15

von Bodungen B, Smetacek V, Tilzer MM, Zeitszschel B (1986) Primary production and sedimentation during spring in the Antarctic Peninsula region. Deep-Sea Res $33: 177-194$

von Bodungen B. Nothig EM, Sui Q (1988) New production of phytoplankton and sedimentation during summer 1985 in the South Eastern Weddell-Sea. Comp Biochem Physiol 90:475-487

Wakeham SG (1982) Organic matter from a sediment trap experiment in the equatorial North Atlantic: wax esters, steryl esters, triacylglycerols and alkyldiacylglycerols. Geochim Cosmochim Acta 46:2239-2257

Weeks A, Conte MH, Harris RP, Bedo A, Bellan I, Burkill PH, Edwards ES, Harbour DS, Kennedy H, Llewellyn C, Mantoura RFC, Morales CE, Pomroy AJ, Turley CM (1993) The physical and chemical environment and changes in community structure associated with bloom evolution: the Joint Global Flux Study North Atlantic Bloom Experiment. Deep-Sea Res 40:347-368

Welschmeyer NA, Copping AE, Vernet M, Lorenzen CJ (1984) Diel fluctuation in zooplankton grazing rate as determined from the downward vertical flux of pheopig. ments. Mar Biol 83:263-270

Wright SW, Jeffrey SW (1987) Fucoxanthin pigment markers of marine phytoplankton analysed by HPLC and HPTLC. Mar Ecol Prog Ser 38:259-266

Wright SW, Jeffrey SW, Mantoura RFC, Llewellyn CA, Bjornland T, Repeta D, Welschmeyer N (1991) Improved HPLC method for the analysis of chlorophylls and carotenoids from marine phytoplankton. Mar Ecol Prog Ser 77:183-196 